\title{
Factors Influencing Adherence to Antiretroviral Drugs among HIV Positive Young Women and Adolescent Patients in North Central Nigeria
}

\author{
Article by Folajinmi Oluwasina ${ }^{1}$, Adebimpe Olalekan ${ }^{2}$, Taofeek Adeleye ${ }^{3}$, Bodunde \\ Onifade $^{4}$, Ifeoluwa Makinde ${ }^{5}$, Matthew Adeoye ${ }^{6}$ \\ ${ }^{1,5}$ University of Ibadan, Nigeria \\ ${ }^{2}$ University of Medical Sciences, Ondo State \\ ${ }^{3}$ University of Ilorin, Kwara State \\ ${ }^{4}$ Federal Ministry of Health, Nigeria \\ ${ }^{5}$ University of Ibadan, Nigeria \\ ${ }^{6}$ Obafemi Awolowo University, Nigeria \\ E-mail:drfolajinmioluwasina@gmail.com ${ }^{1}$,lekanadebimpe@gmail.com ${ }^{2}$, \\ damlek1@yahoo.com ${ }^{3}$,funkefade@gmail.com ${ }^{4}$,iphemankind@yahoo.com ${ }^{5}$, \\ adeoye882002@yahoo.co.uk $k^{6}$
}

\begin{abstract}
The impact of HIV in the world especially in sub-Saharan Africa has led to an extraordinary global effort to ensure adherence to antiretroviral (ARV) therapy to treat the disease in every country where HIV is a threat including Nigeria. However, starting patients on ARVs without ensuring full adherence through an adequate support system is likely to lead to treatment failure and the emergence of drugresistant virus which can be transmitted to other. Factors influencing adherence to medication are both patients and service provider related. A descriptive, cross sectional study using a systematic sampling technique to select 473 young women and adolescent living with HIV in North central ART clinics in Nigeria. $77 \%$ of respondents have been on ARV regimen in the last 3 years. About $82 \%$ had good knowledge of medication adherence while $18 \%$ do not understand what adherence to medication means. Most (79\%) of HIV patient's adequate adherence to ART while others (13\%) usually had stopped taking their medication when they feel better about their health. The commonest source of information about medication adherence to ARV was through the adherence counselor at during ART clinics (77\%). Sixty percent of the respondents agreed that adherence to ARV medication helps in improving standard of living Factors that hindered effective adherence to treatment included poor providers' attitude (28\%) and forgetfulness to take their medication and pill burden (25\%). Respondents who did not adhere to treatment were less likely to subsequently adhere to ARV medication $(O R=0.258,95 \% C I=0.1-0.5)$. Use of treatment supporters was the major determinant of medication adherence $(O R=4.2,95 \% C I=$ 1.4-7.2). Majority of the respondents are knowledgeable about medication adherence.
\end{abstract}

Keywords: Adolescent, Antiretroviral therapy, HIV, Adherence, Young women.

\section{Introduction}

The human immunodeficiency virus (HIV) continues to take a tremendous toll on human health, with 37 million people infected and 1.2 million deaths worldwide in 2014. In sub-Saharan Africa, where the HIV epidemic has been most devastating, more than 25 million people are HIV-infected, about 70 percent of the global total (UNAIDS, 2015).

The overwhelming impact of HIV in the world especially in sub-Saharan Africa has led to an extraordinary global effort to ensure access to antiretroviral (ARV) therapy to treat the disease in every country where HIV is a threat including Nigeria. While the World Health Organization (WHO) goal of ensuring access to antiretroviral treatment (ART) for 3 million people by end of 2008 was not achieved, it continues to take a tremendous toll on human health, with 37 million people infected and 1.2 million deaths worldwide (UNAIDS, 2014). In sub-Saharan Africa, where the HIV epidemic has been most devastating, more than 25 million people are HIV-infected, about 70 percent of the global total(UNAIDS, 2015). 
The roll-out of ARVs in many resource poor countries has been a remarkable expression of international solidarity. However, starting patients on ARVs without ensuring full adherence through an adequate support system is likely to lead to treatment failure and the emergence of drug-resistant virus which can be transmitted to others. Drug-resistance is a potentially major threat to achieving universal access as it could mean that more and more people have to switch to second-line ARVs, which are more expensive and more difficult to use thereby increasing programme costs which will reduce the total number of people with access to treatment.

With the high number of deaths, AIDS is likely to pose significant human resources challenge to the country. With the epidemic picture, which shows urban and young population having higher seroprevalence, it is likely that the disease will disproportionately affect young professionals. It is of utmost concern to know that its impact will be felt in every area of human endeavour, including the educational, health, faith-based organizations, agricultural and defense sectors, among others (National policy for HIV and AIDS, 2009).

Anti-Retroviral Therapy (ART) has improved the quality of life of Human immunodeficiency virus (HIV) patients worldwide. A reduction in HIV-related morbidity and mortality has been recognized in countries where ART has been made widely available. Acquired immune deficiency syndrome (AIDS) is now a manageable chronic illness. To achieve optimal results from ART, high levels of patient adherence to ART is essential. High levels of adherence to ART (at least 95\%) is needed to ensure optimal benefits.

Adherence is defined as a patient's ability to follow a treatment plan, take medications at prescribed times and frequencies, and follow restrictions regarding food and other medications Adherence is a problem in any chronic disease and an average non-adherence rate of $24.8 \%$ have been reported. Suboptimal adherence to ART may ultimately lead to failure of primary regimen. The national guidelines in India stipulates $>95 \%$ adherence to ART.

There are many barriers to adherence in both developed and developing countries. It is important to identify factors that lead to non-adherence and develop strategies to improve long-term adherence. AntiRetroviral Therapy (ART) has improved the quality of life of Human immunodeficiency virus (HIV) patients worldwide. A reduction in HIV-related morbidity and mortality has been recognized in countries where ART has been made widely available. Acquired immune deficiency syndrome (AIDS) is now a manageable chronic illness. To achieve optimal results from ART, high levels of patient adherence to ART is essential. High levels of adherence to ART (at least 95\%) is needed to ensure optimal benefits.

Adherence is defined as a patient's ability to follow a treatment plan, take medications at prescribed times and frequencies, and follow restrictions regarding food and other medications Adherence is a problem in any chronic disease and an average non-adherence rate of $24.8 \%$ have been reported. Suboptimal adherence to ART may ultimately lead to failure of primary regimen. The national guidelines in India stipulates $>95 \%$ adherence to ART.

There are many barriers to adherence in both developed and developing countries. It is important to identify factors that lead to non-adherence and develop strategies to improve long-term adherence.

Poor adherence to antiretroviral drugs during pregnancy can lead to suboptimal viral suppression, development of viral resistance, higher risk of mother-to-child transmission, and mother-to-child transmission of resistant HIV strains (Hayman et al, 2009).

Interrupting medication permits the virus to resume rapid replication and as many as 1010 viral particles will be produced per day, this allows resistant mutant strains to be generated which are no longer responsive to available antiretroviral drugs, posing a public health danger (Murphy et al, 2002). Adherence to antiretroviral drugs poses unique challenges to HIV infected persons particularly in pregnant women. Improving adherence among pregnant women therefore requires knowledge of the factors that influence adherence.

Several methods have been used to measure adherence, but no gold standard has been established (Nachega et al, 2016). Each of these methods has its respective strengths and weaknesses. Available methods include pill counts, self-report, prescription refills, medication event monitoring system (MEMS), biological markers, and assays (Holzemer et al, 2005) 
Though several studies in Nigeria have evaluated the factors associated with nonadherence to antiretroviral therapy among HIV-positive adults, only one from literature search studied antiretroviral adherence issues in HIV-positive pregnant women (Igwegbe, 2010).

They deduced from their study that the determinants of nonadherence to antiretroviral drugs in HIVpositive pregnant women were low level of education, nondisclosure of HIV status, and longer duration of therapy (Igwegbe, 2010).

Adherence to medication is influenced, among other factors by the knowledge of and attitude towards the drugs. Medication adherence, particularly for complex regimens such as highly active antiretroviral therapy (HAART), is a complex behavior, requiring patients to remember multiple medications and dosing schedules (Whitley, 2009). A theoretical framework encompassing cognitive factors has been suggested by researchers who assert that health behavior modification like ARV adherence requires knowledge, skills, and self-efficacy (Cervone, 2004). Knowledge has been defined variously as awareness of personal health status as well as general knowledge of the afflicting condition. Studies have also reported that understanding of medication effectiveness is associated with better adherence (Bennet et al, 2005), while inadequate knowledge and confusion have been associated with lower adherence (Au J, 2006). In Nigeria and other African countries, several studies have reported the relationship of knowledge with adherence to medications in patients with chronic diseases such as hypertension and diabetes mellitus. However, there is a paucity of data on knowledge and attitude of PLWHA on ARV.

Despite several interventions, non-adherence to antiretroviral therapy (ART) remains a barrier to achieving its maximum benefits of HIV treatments. High-levels of sustained adherence have been demonstrated to be directly associated with a decline in the babies' HIV acquisition risk and viral load suppression and increased life expectancy in the mother. In contrast, poor adherence to ART has been associated with poor treatment outcomes, emergence of resistance, patients' dissatisfaction, increased healthcare expenditure, and avoidable deaths.

Previously reported barriers to antiretroviral (ARV) medication adherence include: ART side-effects, social stigma, depression, non-disclosure of HIV status, unemployment, food insecurity, alcohol/substance abuse, alternative forms of therapy, inadequate follow-ups, stock outs, work and family responsibilities, low self-efficacy, low treatment satisfaction and distance to clinics. The factors associated with non-adherence also vary contextually. For instance, knowledge can be linked to nonadherence. Lack of emotional and financial support from husband, inadequate counselling and internal migration could also be reasons for non-adherence to ART.

\section{Methods}

Description of the study area North Central Nigeria (also known as the Middle-Belt region) consists of the seven states situated geographically spanning from the west, around the confluence of the River Niger and the River Benue. The region itself is rich in natural land features and boasts some of Nigeria's most exciting scenery. The region is also home to many historical and colonial relics. The facilities providing ART services includes the Secondary and private healthcare facilities across FCT. ARVs are obtained through the support of PEPFAR and all site providing ART services are all linked to the drug pool system.

\section{Study design}

This study is a descriptive cross sectional study design.

\section{Study population}

The study population consists of young women and adolescents living with HIV (PLHIV) who have been enrolled into care and commenced antiretroviral therapy within the last 2-3 years.

\section{Inclusion criteria}

People Living with HIV from the age of $10-24$ years who have attended clinic for more than 5 times at any of the ART centers for more than two years. This will validate that the patients have 3 or 4 mandatory adherence sessions. 
DOI: 10.21522/TIJPH.2013.SE.19.01.Art015

ISSN: 2520-3134

\section{Exclusion criteria}

People living with HIV from the age of $10-24$ years who are not clinically stable or are not within the enumerated area will not considered. PLHIV below 10 years and above 24 years of age as at this time of the study were not considered.

\section{Sample size}

The sample size was 473 young women and girls living with HIV

\section{Results}

473 respondents were voluntary sampled for the study. The commonly occurring age group of respondents who participated in the study were patients aged 14- 24 years

Most $(56 \%)$ of respondents were married while $(44 \%)$ were never married as at the time of the survey. (58.5\%) respondents completed primary level of education and 39\% had up to secondary education while $5.6 \%$ did not have formal education.

However, a large proportion (87.4\%) of respondents have been on ARVs regimen for years compared with $12.6 \%$ who claimed they were just enrolled on the regimen about a month prior this study.

Table 1. Socio-economic characteristics of respondents

\begin{tabular}{|l|c|c|}
\hline Characteristics & $\begin{array}{c}\text { Frequency } \\
(\mathrm{N}=473)\end{array}$ & $\begin{array}{c}\text { Percentage } \\
(\%)\end{array}$ \\
\hline Age (in Years) & & \\
\hline $10-14$ & 26 & 5.4 \\
\hline $15-19$ & 196 & 41.4 \\
\hline $20-24$ & 251 & 53.1 \\
\hline
\end{tabular}

Medication Adherence Practices among People Living with HIV respondents' medication adherence practices among people living with HIV in the study location. Over one-third (35.2\%) of people living with HIV sampled for this study have been on ARV therapy above five years and over one-tenth $(12.1 \%)$ of them were on the therapy for about 2-3years, while those who were on it less than three months were the least participants of this study (9.8\%). Obviously, a large proportion $(80.3 \%)$ of respondents were on the first line regimen as at the time of the study compared with second line and third line regime $(19.2 \% \& 0.5 \%)$ respectively.

Considering the adherence practices of respondents, it was observed that respondents who didn't usually forget to take their regimen were more than those who usually forget to take the regime $(62.8 \%$ vs. 37.2\%). But majority (86.8\%) were opined that they had never been careless to take the ARV medicine compared with $13.2 \%$ who said so. More than half $(51.3 \%)$ claimed that they never skipped their medications, but $19.5 \%$ said within the past week prior this survey they had missed taking their ARV regimen. A large proportion of respondents exclaimed that they never stopped their ARVs drugs whenever they feel better about their health compared with $6.3 \%$ who claimed they had stopped taking the regimen when they felt they were feeling okay with their health. Also, majority (95.5\%) of the respondents claimed sometimes if they feel worse, they never stopped taking the regimen.

Majority $(97.5 \%)$ of respondents claimed adherence counselling is mandatory before commencing ARVs compared with $1.4 \%$ who didn't know about adherence counselling. Two-third $(67.0 \%)$ of respondents who participated in the study claimed that whenever they missed my drugs for a day, they will take it the next day while one-quarter $(25.5 \%)$ said they never take it next day they missed the regimen. Also, a large proportion (96.8\%) of respondents were of the fact that $100 \%$ adherence is desired for people living with HIV and $94.0 \%$ agreed that they have been adhering to their drugs, and would like to continue in such way compared with $4.1 \%$ who were not sure of continuing in such pattern. 
Table 3. Perception of medication adherence

\begin{tabular}{|c|c|c|c|c|c|c|c|c|}
\hline Statement & $\begin{array}{l}\text { Strongly } \\
\text { Disagree } \\
(\%)\end{array}$ & $\begin{array}{l}\text { Disagree } \\
(\%)\end{array}$ & $\begin{array}{l}\text { Neither } \\
\text { Agree or } \\
\text { Disagree } \\
(\%) \\
\end{array}$ & $\begin{array}{l}\text { Agree } \\
(\%)\end{array}$ & $\begin{array}{l}\text { Strongly } \\
\text { Agree } \\
(\%)\end{array}$ & $\mathbf{n}$ & $\sum X i$ & $\begin{array}{l}\text { Mean } \\
\text { Ratting } \\
\left(\frac{\sum \times \mathbf{X}}{n}\right)\end{array}$ \\
\hline $\begin{array}{l}\text { If you do not take this } \\
\text { medication exactly as } \\
\text { instructed, the HIV in your } \\
\text { body will become resistant to } \\
\text { HIV medications }\end{array}$ & 10.3 & 1.7 & 6.3 & 31.9 & 49.7 & 746 & 3051 & 4.09 \\
\hline $\begin{array}{l}\text { ARVs have positive effect on } \\
\text { your health }\end{array}$ & 8.5 & 2.8 & 6.1 & 39.8 & 42.8 & 739 & 2996 & 4.05 \\
\hline $\begin{array}{l}\text { I fully understand what my } \\
\text { doctor, nurse or the people at } \\
\text { my pharmacy have explained } \\
\text { to me so far }\end{array}$ & 2.4 & 1.2 & 4.3 & 41.9 & 50.2 & 745 & 3250 & 4.36 \\
\hline $\begin{array}{l}\text { I can mention the names of } \\
\text { my medicines and their scope } \\
\text { without hesitation }\end{array}$ & 31.2 & 20.0 & 13.9 & 22.4 & 12.6 & 706 & 1873 & 2.65 \\
\hline $\begin{array}{l}\text { I trust my doctor and agree to } \\
\text { my therapy plan together with } \\
\text { him }\end{array}$ & 2.9 & 0.8 & 4.4 & 45.9 & 46.0 & 730 & 3149 & 4.31 \\
\hline $\begin{array}{l}\text { My medications help me only } \\
\text { if I take them absolutely } \\
\text { regularly as recommended }\end{array}$ & 3.9 & 0.4 & 4.6 & 42.1 & 49.0 & 745 & 3218 & 4.32 \\
\hline $\begin{array}{l}\text { Medicines are all poisonous. } \\
\text { You should avoid taking } \\
\text { medicines at all if possible }\end{array}$ & 70.1 & 17.4 & 5.8 & 2.4 & 4.3 & 747 & 1145 & 1.53 \\
\hline $\begin{array}{l}\text { I feel basically healthy. } \\
\text { Therefore, I am sometimes } \\
\text { unsure whether I really have } \\
\text { to take my medicines daily }\end{array}$ & 54.7 & 23.1 & 6.7 & 9.2 & 6.3 & 746 & 1413 & 1.89 \\
\hline $\begin{array}{l}\text { I take my medicines every } \\
\text { day automatically at a fixed } \\
\text { time or on fixed occasions }\end{array}$ & 8.0 & 5.6 & 8.3 & 38.9 & 39.3 & 738 & 2922 & 3.96 \\
\hline $\begin{array}{l}\text { I frequently forget things on } \\
\text { an everyday basis }\end{array}$ & 56.4 & 28.1 & 5.0 & 8.4 & 2.0 & 737 & 1264 & 1.72 \\
\hline $\begin{array}{l}\text { Generally, I often feel bad, } \\
\text { and sometimes I feel } \\
\text { discouraged and depressed. }\end{array}$ & 50.2 & 14.7 & 7.4 & 12.7 & 14.9 & 739 & 1680 & 2.27 \\
\hline $\begin{array}{l}\text { I frequently have problems } \\
\text { taking my medications or it is } \\
\text { difficult for me to keep me on } \\
\text { the accompanying conditions } \\
\text { of the medication intake }\end{array}$ & 57.1 & 33.6 & 5.4 & 2.7 & 1.2 & 739 & 1163 & 1.57 \\
\hline $\begin{array}{l}\text { I really would need help on } \\
\text { an everyday basis (and } \\
\text { particularly related to my } \\
\text { treatment with medicines). } \\
\text { But I do not get any help }\end{array}$ & 56.7 & 29.2 & 2.7 & 5.5 & 5.8 & 739 & 1290 & 1.75 \\
\hline
\end{tabular}


DOI: 10.21522/TIJPH.2013.SE.19.01.Art015

ISSN: $2520-3134$

\begin{tabular}{|l|l|l|l|l|l|l|l|l|}
\hline $\begin{array}{l}\text { I am really frightened of the } \\
\text { side effects of my medicines. }\end{array}$ & 59.4 & 21.7 & 4.3 & 9.2 & 5.3 & 737 & 1321 & 1.79 \\
\hline $\begin{array}{l}\text { In case I already noticed or in } \\
\text { case I would notice side } \\
\text { effects related to my } \\
\text { medicines: I have talked or } \\
\text { would talk to my doctor about } \\
\text { them as soon as possible }\end{array}$ & 5.0 & 2.3 & 2.7 & 30.1 & 59.9 & 744 & 3257 & 4.38 \\
\hline $\begin{array}{l}\text { In case I already noticed or in } \\
\text { case I would notice side } \\
\text { effects related to my } \\
\text { medicines: I have } \\
\text { stopped/would stop my } \\
\text { medications or took/would } \\
\text { take less of them }\end{array}$ & 69.1 & 17.8 & 3.7 & 4.5 & 5.0 & 737 & 1169 & 1.59 \\
\hline
\end{tabular}

Strongly Agree -5, Agree - 4, Undecided - 3, Disagree - 2, Strongly Disagree - 1

Logistics Regression Model of Factors Influencing Medication Adherences of Patients to Antiretroviral Therapy.

Logistic regression was used to test associations between various factors and medication adherence in the study locations. Multivariate analysis was therefore used to test the degree of associations between independent and dependent variables which were assessed using odds ratios. The overall model in table 8 shows that factors identified were good predictors of dependent variable - carelessness in

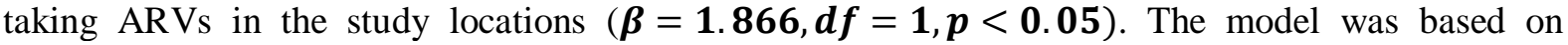
dichotomous response variable - poor adherence (0) and good adherence (1) and /or categorical explanatory variable(s), which are various factors affecting medication adherence to treatments. Thus, for every patient adherence,

$\boldsymbol{\beta}=0 \Rightarrow \mathrm{P}$ (adherence) is the same at each level of $\mathrm{x}$

$\boldsymbol{\beta}>0 \Rightarrow \mathrm{P}($ adherence $)$ increases as $\mathrm{x}$ increases

$\boldsymbol{\beta}<0 \Rightarrow \mathrm{P}($ adherence $)$ decreases as $\mathrm{x}$ increases

Therefore, the Odd Ratio (OR) is determined in the same model explaining how more likely factors are able to influence ARVs medication adherences.

Majority (87.9\%) of respondents however, agreed that they won't allow any obstacle to prevent me from holistically taking my ARVs, about one in ten (12.4\%) of respondents still don't mind missing ARVs on some days. Close to one-fifth (17.3\%) of respondents agreed that there would be no consequences if they miss ARVs on some days but disagreed by majority (73.3\%). Respondents who wish to soon discontinue ARVs was $9.1 \%$ and those who were not sure accounted for $8.4 \%$.

Respondents who want to start to combine herbal and alternative therapy with ARVs were very small compared with those who disagreed with such attitude (4.1\% Vs. $90.1 \%)$. While $69.3 \%$ of respondents claimed they would not like to skip my drug collection appointment days and $98.0 \%$ said they would keep to their appointment's days related to drugs taking and adherence. A large proportion $(99.1 \%)$ of respondents agreed to keep to the ARVs dosing, frequency and time.

Table 5 shows respondents' perception towards medication adherence in the study location. Obviously considering the mean ratting of respondents, majority of them averagely agreed that if they didn't take this medication exactly as instructed, the HIV in their body will become resistant to HIV medications (4.09) while they averagely perceived that ARVs have positive effect on their health (4.05).

Also, majority of respondents averagely agreed that they fully understood what doctor, nurse or the people at my pharmacy had explained to them so far (4.36). Majority of respondents averagely neither agreed nor disagreed that they could either mention the names of the medicines and their scope without hesitation (2.65).

Meanwhile, majority of respondents averagely agreed that they trusted their doctor and also agreed to their therapy plan together with the doctor (4.31), and respondents also agreed that their medications helped them only if they take them absolutely regularly as recommended (4.32). 
Respondents averagely disagreed that medicines are all poisonous and should avoid taking medicines at all if possible (1.53). in the similar vein, respondents averagely disagreed to the statement that they when feel basically healthy, they therefore sometimes unsure whether they would really have to take my medicines daily (1.89).

Respondents averagely agreed that they took their medicines every day automatically at a fixed time or on fixed occasions (3.96), while majority disagreed to the fact that they frequently forget things on an everyday basis (1.72) and disagreed that generally they often feel bad, and sometimes feel discouraged and depressed (2.27).

Considering problems regarding medications, respondents averagely disagreed that they frequently have problems taking their medications or it's difficult to keep on the accompanying conditions of the medication intake (1.57) and also disagreed that they would need help on an everyday basis particularly related to treatment with medicines. It was averagely disagreed that respondents were really frightened of the side effects of my medicines (1.79)

Respondents averagely agreed that in case they noticed or would notice side effects related to the medicines; they would talk to their doctors about any side effects as soon as possible (4.38) and strongly disagreed that they would stop taking medications or taking less if they had notice of any side effects related to their medicine (1.59).

Table 4. Variables in the equation

\begin{tabular}{|l|l|l|l|l|l|l|}
\hline & $\begin{array}{l}\text { Beta } \\
\text { Coefficient }\end{array}$ & $\begin{array}{l}\text { Standard } \\
\text { Error }\end{array}$ & Wald Statistics & $\begin{array}{l}\text { Degree of } \\
\text { Freedom }\end{array}$ & P-value & $\begin{array}{l}\text { Odd Ratio } \\
\text { (OR) }\end{array}$ \\
\hline Constant & 1.866 & 0.117 & 253.379 & 1 & $0.000 *$ & 6.464 \\
\hline
\end{tabular}

$* \mathrm{P}<0.05$

Considering the factors affecting medication adherence, the logistics regression model shows that there was significant association between proximity/ closeness of ART centres to patients' house and medication adherence. Thus, proximity of patients' house or nearest to the ART centres is 0.180 times more likely to influence medication adherence $(\boldsymbol{\beta}=-\mathbf{1 . 7 1 6}$, Odd Ratio $[O R]=0.180, p<$ 0. 05). As distance to ART centres decreases, then medication adherences increases.

Also, there was a significant relationship between refusal of service at patients' ATR clinics during working hours in the past for any reason and their medication adherence. Prompt service to people living with HIV without hesitation is 28.577 times more likely to influence adherence medication $(\boldsymbol{\beta}=$ 3.353, Odd Ratio $[O R]=28.577, p<0.05)$. This implies that, the more the prompt ART services increases the more the adherence of the medications.

In the same vein, there was a significant association between financial constraints for patients in seeking medical services with respect to the use of ARVs and good medication adherence. Financial constraints of patients living with HIV in seeking medical services is 6.543 times more likely to influence medication adherences in the study location $(\boldsymbol{\beta}=\mathbf{1 . 8 7 8}$, Odd Ratio $[$ OR $]=6.543, p<$ $\mathbf{0 . 0 5}$ ). This means that an increase in financial resources of the patients will increase their medication adherences.

The religious belief system of people living with HIV is significant associated with their medication adherences. The decrease in the religious belief system will increase medication adherences of ART. The religion of patients is 0.167 times more likely to influence medication adherences $(\boldsymbol{\beta}=$ -1.793, Odd Ratio $[O R]=0.167, p<0.05$ ).

In light of these, only proximity/ closeness of ART centres to patients' house, refusal of service at patients ATR clinic during working hours for any reason, financial constraints for patients in seeking medical services and religious belief system of patients become strong influencing factors that influence mediation adherences to treatment of people living with HIV. 
DOI: 10.21522/TIJPH.2013.SE.19.01.Art015

ISSN: 2520-3134

Table 5. Logistics regression model of factors influencing medication adherences

\begin{tabular}{|c|c|c|c|c|c|c|}
\hline $\begin{array}{l}\text { Dependent Variable: Respondents ever } \\
\text { careless in taking ARVs in the past }\end{array}$ & $\begin{array}{l}\text { Beta } \\
\text { Coefficient }\end{array}$ & $\begin{array}{l}\text { Standard } \\
\text { Error }\end{array}$ & $\begin{array}{l}\text { Wald } \\
\text { Statistics }\end{array}$ & $\begin{array}{l}\text { Degree of } \\
\text { Freedom }\end{array}$ & P-value & $\begin{array}{l}\text { Odd } \\
\text { Ratio } \\
\text { (OR) }\end{array}$ \\
\hline Constant & -2.182 & 3.046 & 0.513 & 1 & 0.474 & 0.113 \\
\hline $\begin{array}{l}\text { Existences of barriers in seeking medical } \\
\text { services regarding ART }\end{array}$ & 0.619 & 0.365 & 2.871 & 1 & 0.090 & 1.857 \\
\hline $\begin{array}{l}\text { Preference locations of ART medical } \\
\text { services }\end{array}$ & 0.008 & 0.198 & 0.001 & 1 & 0.969 & 1.008 \\
\hline $\begin{array}{l}\text { Proximity/ closeness of ART centres to } \\
\text { patients house }\end{array}$ & -1.716 & 0.439 & 15.276 & 1 & $0.000^{*}$ & 0.180 \\
\hline Nearest centre to patients house & 0.158 & 0.203 & 0.608 & 1 & 0.435 & 1.171 \\
\hline $\begin{array}{l}\text { Denial to receiving ARVs drugs from } \\
\text { clinic before }\end{array}$ & -0.835 & 0.907 & 0.849 & 1 & 0.357 & 0.434 \\
\hline $\begin{array}{l}\text { Refusal of service at patients ATR clinic } \\
\text { during working hours before for any } \\
\text { reason }\end{array}$ & 3.353 & 0.889 & 14.234 & 1 & $0.000^{*}$ & 28.577 \\
\hline $\begin{array}{l}\text { Convenience hours the facility open for } \\
\text { patients }\end{array}$ & 0.871 & 1.028 & 0.717 & 1 & 0.397 & 2.389 \\
\hline $\begin{array}{l}\text { Money constraints for patients in seeking } \\
\text { medical services }\end{array}$ & 1.878 & 0.320 & 34.418 & 1 & $0.000^{*}$ & 6.543 \\
\hline Buying ARVs in the past & 0.001 & 1.014 & 0.000 & 1 & 0.999 & 1.001 \\
\hline Religious belief system of patients & -1.793 & 0.701 & 6.540 & 1 & $0.011 *$ & 0.167 \\
\hline
\end{tabular}

$* \mathrm{P}<0.05$

\section{Conclusion}

Majority are aware of the benefits of adhering to treatment. One of the major influencer of medication adherence is treatment supporter who have significantly helped participants to stick to their medication. However, it is important to take the young women and girls into consideration when designing programs that can scale up adherence to treatment in HIV programs. An organized comprehensive education on medication adherence that is responsive to the need of young women and adolescent girls is important and may become a necessity for these challenges associated to living healthy.

\section{Citations}

Folajinmi Oluwasina et al, 2018: Factors influencing adherence to antiretroviral drugs among HIV positive young women and adolescent patients in north central Nigeria

\section{Acknowledgements}

I acknowledge the 473 young women and adolescent patients (respondents) who participated in this study for their time and patience.

\section{References}

[1].Ampofo KW. (2009). Editorial commentary: Current status of HIV/AIDS treatment, care and support services in Ghana. Ghana Med J. 43(4):142-143.

[2].Adherence Working Group of the Outcomes Committee of the Adult AIDS Clinical trials Group. (2010). AIDS Care; 12:255-66.

[3].Bangsberg DR, Moss AR, Deeks SG. (2010) Paradoxes of Adherence and Drug Resistance to HIV Antiretroviral Therapy. J Antimicrob Chemother; 53:696-9.

[4].Bennet SJ, Lane KA, Welch J, Perkins SM, Brater CD (2006). Medication and Dietary Compliance Beliefs in Heart Failure. Western Journal of Nursing Research. 27(8): 977-993. 
[5].Brass AL, Dykxhoorn DM, Benita Y, Yan N, Engelman A, Xavier RJ, Lieberman J, Elledge SJ. (2008). Identification of host proteins required for HIV infection through a functional genomic screen.319:921-926.

[6].Catz, S., Heckman, T.G., Kochman, A.R., \&DiMarco, M. (2011). Rates and predictors of adherence to HIV medications among late middle-aged and older adults living with HIV/AIDS. Psychology, Health, and Medicine, 6, 47-58.

[7].Cervone D. (2004). Thinking about self-efficacy. Behavior Modification. 24(1): 30-56.

[8].DanelC. (2016). Early ART and IPT in HV-infected African adults with high CD4 count (Temprano trial).2016 Conference on Retroviruses and Opportunistic Infections (CROI), Seattle, USA,

[9].Chesney MA, Ickovics JR, Chambers DB, Gifford AL, Neidig J, Zwickl B. (2014) Self-Reported Adherence to Antiretroviral Medications Among Participants in HIV Clinical Trials; the AACTG Adherence Instruments. Patients care Committee and Adherence

[10]. Fonner VA, Denison J, Kennedy CE, O'Reilly K, Sweat M. (2012) Voluntary counseling and testing (VCT) for changing HIV-related risk behavior in developing countries. The Cochrane Library.

[11]. Fonner VA, Denison J, Kennedy CE, O'Reilly K, Sweat M. (2012). Voluntary counseling and testing (VCT) for changing HIV-related risk behavior in developing countries. The Cochrane Library;

[12]. Global Burden of Disease Pediatrics Collaboration. Global and national burden of diseases and injuries among children and adolescents between 1990 and 2013. (2016) Findings from the global burden of disease 2013 study. JAMA Pediatrics. 170(3):267-87.

[13]. Igwegbe O, Ugboaja J.O, Nwajiaku L.A (2010) "Prevalence and determinants of non-adherence to antiretroviral therapy among HIV- positive pregnant women in Nnewi, Nigeria," International Journal of Medicine and Medical Sciences, vol. 2, no. 8, pp. 238-245, 2010. View at Google Scholar.

[14]. Kouanda S, Bocoum FY, Doulougou B, Bila B, Yaméogo M, Sanou MJ, Sawadogo M, Sondo B, Msellati P, Desclaux A. (2010). User fees and access to ARV treatment for persons living with HIV/AIDS: implementation and challenges in Burkina Faso, a limited-resource country. AIDS Care. 22(9):1146-1152.

[15]. Mutevedzi PC, Newell M. (2014) the changing face of the HIV epidemic in sub-Saharan Africa. Trop Med Int Health. 19(9):1015-1028. doi: 10.1111/tmi.12344.

[16]. Nachega, J.B A. R. Knowlton, A. Deluca 1 (2006). "Treatment supporter to improve adherence to antiretroviral therapy in HIV-infected South African adults: a qualitative study," Journal of Acquired Immune Deficiency Syndromes, vol. 43, supplement 1, pp. S127-S133.

[17]. Palella FJ, Delaney KM, Moorman AC, Loveless MO, Fuhrer J, Satten GA, (2014). Declining Morbidity and Mortality among Patients with Advanced HIV Infection - HIV Out-Patients Study Investigations. N Engl J Med. 338:853-60.

[18]. Paterson DL, Swindell S, Mohr J, Brester M, Vergis E, Squire S. (2009) Adherence to Protease Inhibitor Therapy and Outcomes in Patients with HIV Infection. Ann Intern Med. 133:21-30.

[19]. Takarinda KC, Madyira LK, (2016). Factors associated with ever being HIV-tested in Zimbabwe: An extended analysis of the Zimbabwe Demographic and Health Survey (2010-2011). PLoS ONE. 2016; 11(1):118. doi: 10.1371/journal.pone.0147828 .

[20]. WHO. Guidelines on HIV self-testing and partner notification: supplement to consolidated guidelines on HIV testing services. (2016). Geneva, Switzerland: World Health Organization.

[21]. W. L. Holzemer, I. B. Corless, K. M. Nokes et al. (2009). "Predictors of self-reported adherence in persons living with HIV disease,” AIDS Patient Care and STDs, vol. 13, no. 3, pp. 185-197,

[22]. Whitley HP, Fermo JD, Ragucci K, Chumney EC. (2009). Assessment of patient knowledge of diabetic goals, self-reported medication adherence, and goal attainment. Pharmacy Practice. 4(4): 183-190.

[23]. WHO. (2015). Global health sector response to HIV: Focus on innovations in Africa: Progress report. Geneva, Switzerland: World Health Organization.

[24]. UNAIDS. (2015) Access to antiretroviral therapy in Africa: status report on progress towards the 2015 targets. Geneva, Switzerland: UNAIDS; 2015

[25]. UNAIDS. (2014) 90-90-90 An ambitious treatment target to help end the AIDS epidemic. Geneva, Switzerland: UNAIDS.

[26]. UNAIDS. (2015). Access to antiretroviral therapy in Africa: status report on progress towards the 2015 targets. Geneva, Switzerland: UNAIDS; 2015.

[27]. WHO.(2015.) Antiretroviral therapy; http://www.who.int/topics/antiretroviral_therapy/en/ 
DOI: 10.21522/TIJPH.2013.SE.19.01.Art015

ISSN: $2520-3134$

[28]. WHO. (2013). Number of people receiving antiviral therapy (ART) and percentage of all people living with HIV receiving ART in low- and middle-income countries overall and by WHO region, 2013. 